\title{
Freshman Attrition in a College of Applied Arts and Technology of Ontario
}

\author{
PETER H.J. DIETSCHE*
}

\section{ABSTRACT}

This study, conceptualized using a "person-environment fit" model of dropout, examined differentiated freshman attrition and persistence in a College of Applied Arts and Technology of Ontario. Also examined were the magnitude and timing of dropout as well as the ability of the model to explain and predict freshman attrition/persistence vs academic success/failure. The relative importance of student and institutional characteristics in the withdrawal process was also assessed. Results showed that thirty percent of the freshman cohort dropped out in the first year, with approximately half doing so in the first semester. Those variables which measured the nature of the student-institution interaction accounted for a greater amount of the variance in persistence/withdrawal than did the background and entry-level characteristics of the students alone. This confirms the validity of the "fit" model of dropout and suggests that college administrators could significantly reduce freshman attrition by carefully managing the college learning environment. Consistent with U.S. studies comparing factors influencing dropout in commuter and residential institutions, this study found academic integration and educational commitment to be of greater importance to persistence than social integration and institutional commitment. A student's intention to leave the college at mid-semester and his/her confidence in success were also found to be important determinants of freshman attrition.

\section{RÉSUMÉ}

Cette enquête, menée à partir d' un modèle visant à faire ressortir la concordance entre la personnalité et l' environnement du décrocheur, passe en revue les divers comportements des étudiants de première année vis-à-vis l'abandon ou la persévérance dans un collège d'arts appliqués et de technologie de l'Ontario. $D$ 'autres facteurs ont été pris en compte tels que la proportion de décrocheurs et le moment où se produit l'abandon des cours; on a tâché de plus de vérifier dans quelle mesure le modèle permettait d'expliquer ou de prévoir l'abandon ou la persévérance des nouveaux étudiants plutôt que leur réussite ou leur échec sur le plan académique. On a tenté d'évaluer par ailleurs quelle était la part de responsabilité à accorder aux caractéristiques personnelles des étudiants au

\footnotetext{
*Human Studies Division, Humber College of Applied Arts and Technology
} 
moment de l'entrée et à celles de l'institution dans la décision d'abandon. Les résultats de la recherche ont montré que trente pour cent de la cohorte des nouveaux étudiants abandonnaient leurs études dans le courant de la première année, dont la moitié dès le premier semestre. Les variables considérées, lesquelles mesuraient aussi le degré d'interaction entre l'étudiant et l'établissement, permirent d'établir que cette interaction comptait nettement plus que le milieu d'origine des étudiants ou leur niveau d' entrée dans la décision d'abandonner des études ou de persévérer. Ceci confirme donc qu'il existe un modèle d'ajustement particulier au décrocheur et laisse entendre que les administrateurs des collèges pourraient réduire considérablement le taux d'abandon dans leur établissement s'ils prenaient soin d'y offrir de bonnes conditions d'apprentissage. Tout comme les recherches américaines qui ont comparé les facteurs d'abandon dans les universités éloignées et dans celles de la région de l'étudiant, cette étude met en lumière que là où il y a intégration intellectuelle et engagement vis-à-vis de l'enseignement, la persévérance est plus grande que là où on se préoccupe surtout d'intégration sociale et d'intérêts institutionnels. Par ailleurs une intention personnelle de quitter le collège en cours de semestre et la confiance de l'étudiant dans sa propre réussite peuvent être également des facteurs d'abandon importants.

\section{INTRODUCTION}

Concern for the wastage of human and financial resources has made student withdrawal behavior in postsecondary education an issue of considerable practical as well as scholarly interest (e.g., Astin, 1975, 1985; Cope \& Hannah, 1975; Lenning, Beal, \& Sauer, 1980; Pantages \& Creedon, 1978; Ramist, 1981; Spady, 1970; Tinto, 1975, 1986). The many studies conducted in the U.S. (Astin, 1972; Bayer, Royer, \& Webb, 1973; Panos \& Astin, 1968; Ramist, 1981) have generally reported the same findings: about 40 percent of entering freshmen nationwide never achieve a baccalaureate degree. Tinto (1982) has found that, as a national phenomenon, attrition has been a surprisingly stable feature of the U.S. higher education enterprise.

While published studies of attrition in Canadian postsecondary institutions are few (Anisef, Paasche, \& Turrittin, 1980; Jones \& Dennison, 1972; Lam, 1984; Mehra, 1973; Pascal \& Kanowitch, 1979; Ungar, 1980), and there have been no national studies, available data suggest that our rates do not differ substantially from those in the U.S. An analysis of withdrawal from the Colleges of Applied Arts and Technology of Ontario (CAATs) between 1974 and 1979 (Stoll \& Scarff, (1983), found total student withdrawal rates of from 44.1 percent to 47.1 percent. For the entire college system, approximately 14,000 students from each of the 1974 to 1979 cohorts failed to graduate, constituting a group of at least 84,000 students who left the Ontario college system without receiving a diploma.

In order to minimize the loss of talent, the waste of limited educational resources, and the vocational, financial, and personal setbacks that result from student attrition in Canadian higher education (Gilbert \& Gomme, 1986; Gomme 
\& Gilbert, 1984), additional information on the dropout process must be obtained. It might be possible to enhance student persistence in colleges by developing and implementing specific institutional policies and practices if it were clear which policies and practices would be most effective. The U.S. research literature indicates that while similarities exist between the variables associated with attrition across institutions, there are significant differences of sufficient magnitude to contraindicate wholesale generalizations from one student body to another, or from one institution to another. A necessary precursor to a reduction in student attrition in the colleges of Ontario, then, is the design and implementation of empirical studies of the phenomenon within the CAAT system. In this way we may arrive at some conclusions regarding the causes of dropout and which institutional policies and practices would improve persistence.

\section{Research Issues}

Research on attrition in the 1980s has largely attempted to validate the person-environment fit models of attrition (Tinto, 1975, 1986) in different types of postsecondary institutions. These studies have identified several issues for continued research.

A number of investigators (Pascarella \& Chapman, 1983; Pascarella, Duby, \& Iverson, 1983; Pascarella, Duby, Miller, \& Rasher, 1981; Terenzini \& Pascarella, 1984) have shown that the variables influencing attrition in commuter institutions differ from those operating in residential colleges and universities. The first major difference found was in the relative contributions of Tinto's (1975) constructs of institutional and goal commitment. Institutional commitment had a much stronger direct effect than goal commitment in residential institutions, while goal commitment had a somewhat stronger direct effect than institutional commitment in the sample of commuter colleges.

A second notable difference across institutions was in the role played by Tinto's central concepts of social and academic integration. The findings suggest that in non-residential institutions, commitment to the college or university at the end of the freshman year is defined largely by successful and personally satisfying interactions with the academic, rather than the social systems of the institution. It may well be that in many commuter institutions the opportunities for social involvement are sufficiently few that the concept of social integration has little meaning in terms of bonds to the institution.

The role of background and student-institution interaction variables in influencing voluntary dropout also appears to differ between commuter and residential institutions. Several studies (Munro, 1981; Pascarella, Duby, \& Iverson, 1983; Pascarella, Duby, Miller, \& Rasher, 1981; Pascarella \& Terenzini, 1983; Terenzini \& Pascarella, 1978) have found that in residential institutions the influence of background characteristics is largely indirect, mediated by social integration, the commitment variables, or living on campus. Conversely, in the commuter colleges the impact of background characteristics on persistence was 
not totally transmitted through the freshman year experience. Rather, high school achievement and affiliation needs had a direct effect on persistence, and goal commitment, which had the largest direct effect on persistence in the commuter institutions, was itself most strongly influenced by background traits such as achievement needs, and uninfluenced by either academic or social integration. An important empirical issue, then, is whether additional differences in the operation of the main constructs of Tinto's $(1975,1986)$ model would be found in a predominantly vocationally oriented commuter institution. The CAATs of Ontario are an ideal venue for such a test.

A final research issue concerns the evaluation of Tinto's (1975) model with differentiated attrition. As many researchers have noted (Kneoll, 1960; Pantages \& Creedon, 1978; Tinto, 1975), two types of dropouts have been described in the literature and have been variously labelled as voluntary withdrawals vs academic dismissals (Tinto, 1975), successful withdrawals vs unsuccessful withdrawals (Hanson \& Taylor, 1970), nonacademic dropouts vs academic dropouts (Starr, Betz, \& Menne, 1972), passing dropouts vs failing dropouts (Prediger, 1965), and achieving withdrawals vs nonachieving withdrawals (Zaccaria \& Creaser, 1971). As the labels imply, the fundamental distinction between the two groups is that one group leaves the college in good academic standing, while the other does not. All tests of the models of dropout described earlier have included only voluntary dropouts or both groups combined; none has assessed the models with both groups included in the dropout sample and differentiated from each other.

\section{A Model of Dropout and Research Objectives}

The model of dropout utilized in this study is an integration of those proposed by Tinto (1975) and Bean (1980). Bean's research (1983) has demonstrated the value of the "intent to leave" variable in accounting for the variance in voluntary dropout, and tests of Tinto's model (Terenzini \& Pascarella, 1980) have indicated the validity of its constructs. The present model is of the longitudinal-process type and specifies four classes of variables; eight background variables, which include demographic characteristics and academic history; fourteen entry-level variables, which describe the characteristics of the student as he or she enters the college, including Tinto's constructs of goal and institutional commitment; five interaction variables, which describe the interaction between the student and the institution and include academic and social integration; and six outcome variables such as intent to leave and persistance/dropout. The interactions between the variables in the model are assumed to be linear and additive in accordance with the assumptions of the required statistical procedures. The hypothesized causal sequence of the variables is also consistent with the theories of Tinto (1975) and Bean (1980). 


\section{A Model of Dropout}

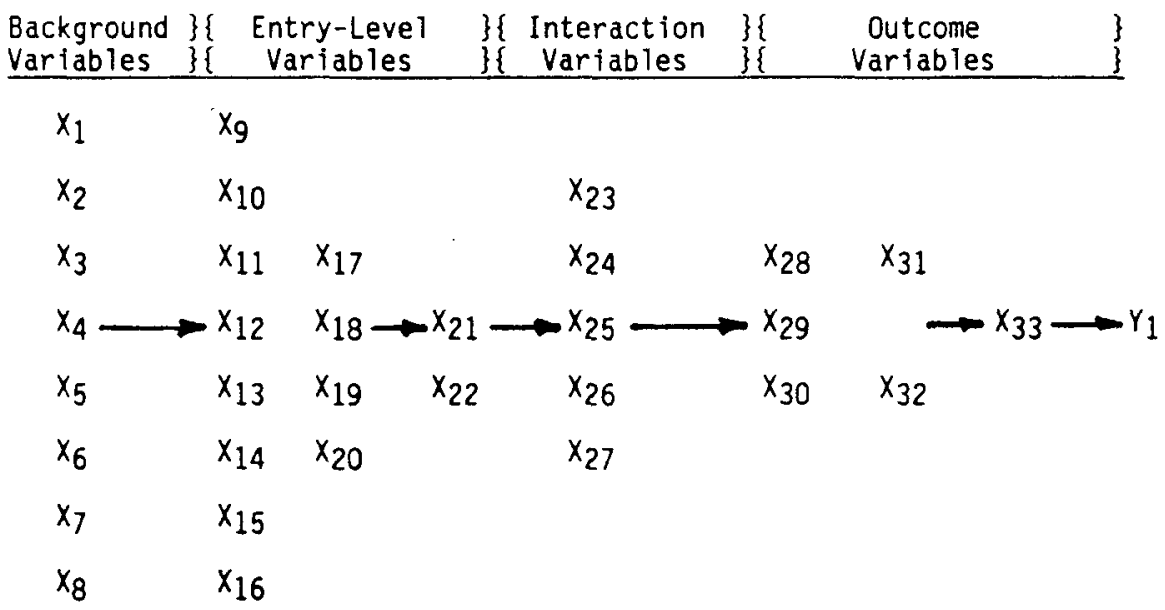

Using attrition research and theory as a guide to minimize specification error (Pedhazur, 1982), the variables selected for inclusion in the model are:

\section{Background Variables}

$x_{1}=$ gender

$x_{3}=$ age

$X_{5}=$ high school program level

$x_{7}=$ high school average

\section{Entry-Level Variables}

$x_{9}=$ financial aid

$x_{11}=$ confidence in success 1

$x_{13}=$ contact with college

$X_{15}=$ value of education 1

$X_{17}=$ rating of college

$x_{19}=$ rating of program

$x_{21}=$ ed. commitment 1 $x_{2}=$ socioeconomic status

$x_{4}=$ mother tongue

$X_{6}=$ high school concentration

$X_{8}=$ level of prior education

$\mathrm{X}_{10}=$ changed residence

$x_{12}=$ educational goals

$x_{14}=$ job orientation 1

$X_{16}=$ academic skill needs

$\mathrm{X}_{18}=$ vocationa 1 uncertainty

$X_{20}=$ concern for finances

$X_{22}=$ inst. commitment 1 


\section{Interaction Variables}

$x_{23}=$ dissatisfaction

$X_{25}=$ actual part-time work

$x_{27}=$ social integration

\section{Outcome Variables}

$\begin{array}{ll}x_{28}=\text { orientation to job } 2 & x_{29}=\text { value of education } 2 \\ x_{30}=\text { confidence in success } 2 & x_{31}=\text { ed. commitment } 2 \\ x_{32}=\text { inst. commitment } 2 & x_{33}=\text { intent to leave } \\ y_{1}=\text { dropout/persist vs success/failure }\end{array}$

The research issues identified above, as well as the paucity of empirical data on dropout in Canadian colleges, indicate a need for further study of differentiated attrition in a non-residential postsecondary institution of technical/vocational education. The objectives of the present study, therefore, were:

1. To describe the magnitude and timing of freshman attrition in a College of Applied Arts and Technology.

2. To identify any differences in the background, entry-level, interaction, and outcome characteristics of successful and unsuccessful dropouts compared to successful and unsuccessful persisters.

3. To estimate the relative importance of academic and social integration, and educational and institutional commitment in distinguishing between the criterion groups.

4. To test the validity of the proposed model of dropout in explaining differentiated attrition in a College of Applied Arts and Technology of Ontario.

5. To assess the relative importance of background and entry-level variables, compared to interaction and outcome variables, in explaining dropout in a commuter institution.

6. To determine whether students can be classified as dropouts or persisters with an accuracy greater than chance, using their background, entry-level, interaction, and outcome characteristics.

\section{METHODS}

The subjects of this study were the 3,879 full-time students beginning their first semester at Humber College of Applied Arts and Technology in the fall of 1986. A longitudinal design was employed rather than an ex post facto methodology since this permits an explanation of factors which affect student withdrawal at the very time they are exerting their effects and provides a clearer view of the interaction of factors which influence student departure. (Tinto, 1975; Eckland, 1964; Jex \& Merrill, 1962; Marks, 1967). 
Freshman characteristics were measured at four points in time. Their background and entry-level characteristics were collected in the first week of classes via the Freshman Survey utilizing a 116 item, largely multiple-choice and Likert type questionnaire. A second set of data reflecting students' interactions with the college was collected approximately two months later via the Student Satisfaction Survey utilizing a 96 item, largely multiple-choice and Likert type questionnaire designed to measure aspects of students' mid-semester attitudes, perceptions, and behavior. At the beginning of the second term students' fall semester mid-term and final grades, as well as their winter 1987 enrollment status, were extracted from the College student records system. This was repeated in the fall of 1987 to determine again the enrollment status of the 1986 cohort. Students were classified as first-or second-semester dropouts, persisters, stopouts, or part-time depending upon their fall 1987 enrollment status.

\section{Independent and Dependent Variables}

The operational definition of each variable in this study was derived either from the dummy coding of a questionnaire item or via principal components factor analysis with varimax rotation. In the latter case the procedure advocated by Terenzini and Pascarella (1977) was used. Only items with loadings above $|0.40|$ were retained for each factor. When an item's loading was greater than 10.401 on more than one factor, the item was assigned to the factor on which it had the highest loading.

Subject's scores on these factor-based variables were computed by first reversing the response values on items where necessary to produce a unidirectional scale, and then converting these raw scores to standardized scores. Factor scores for each subject were then calculated by summing these standardized response values for all items loading on each factor, with a constant of twenty being added in order to eliminate negative values. Additional details on these procedures including complete factor scales and item composition may be found in Dietsche (1989). Each independent variable in this study was operationalized as follows: gender: female $=1$, male $=0$.

socioeconomic status: parents' occupation (Blishen Index) plus parents' highest level of education.

age: age in years.

mother tongue: English $=0$, other $=1$.

high school level: advanced $=0$, general or basic $=1$.

high school concentration: academic $=0$, business $/$ tech. $=1$.

high school average: final average in percent.

high school academic involvement: the sum of three items measuring the frequency with which students studied, skipped classes, and completed homework assignments on time.

level of education: less than or equal to grade 12 graduation $=0$, greater than grade 12 graduation $=1$.

financial aid: not receiving aid $=0$, receiving aid $=1$.

changed residence: did not move $=0$, moved $=1$. 
confidence 1: factorially derived with three Likert items (e.g. "I am certain to complete my program successfully").

educational goals: six-item factorially derived scale measuring students' goals in attending college.

college contact: a four-item scale of student contact with college publications and orientation scored no contact $=1$, contact $=2$.

job orientation 1: a factorially derived scale with two-items (e.g. "I am attending college only until a job is available").

value of education 1: a six-item factorially derived scale measuring a student's perception of the value of his/her education.

academic skill needs: students' assessment of their literacy, numeracy, and study skills development needs scored from $4=$ "could benefit greatly" to $1=$ "of no benefit at all".

rating of college: the student's ranking of college with third-choice $=1$ to first-choice $=3$.

vocational uncertainty: an eight-item factorially derived scale measuring student's uncertainty about their future career.

rating of program: student's rating of his/her program with first-choice $=2$, other $=1$.

concern for finances: a four-item factorially derived scale measuring a student's financial status.

educational commitment 1 : a seven-item factorially derived scale measuring the student's desire to graduate from college.

institutional commitment 1 : a fourteen-item factorially derived scale assessing a student's perceptions of the college.

dissatisfaction: a four-item factorially derived scale reflecting a student's negative feelings regarding faculty, courses, and other students.

use of college services: a measure of student utilization of seven different college services with non-use $=1$ and use $=2$.

actual part-time work: assessed whether a student held a job while enrolled in college with non employment $=0$, and employment $=1$.

college academic involvement: same as high school measure but with reference to academic activities during first two months of college.

academic integration: the sum of two factorially derived variables: perception of program, a 12 item scale measuring a student's perception of his/her program; and academic involvement, a four-item scale measuring frequency of studying, class absenteeism, homework completion, and whether a course had been dropped.

social integration: the sum of three factorially derived variables and one non-factor-based variable: personal development, a seven-item scale measuring the degree of personal growth in college; interaction with faculty, a six-item scale assessing the frequency and nature of interactions with faculty; interaction with peers, a five-item scale describing the student's friendships in college and attitudes toward other students; extracurricular involvement, measured the frequency with which students participated in seven activities such as clubs, organizations, and athletics. 
Table 1: Attrition Rates in the Freshman Year

$\begin{array}{lcc}\begin{array}{l}\text { Dropout } \\ \text { Period }\end{array} & \text { N } & \begin{array}{c}\text { \% of Total } \\ \text { Full-Time Sample }\end{array} \\ \text { First semester } & 538 & 14.1 \\ \text { Second semester } & 608 & 15.9 \\ \text { Total } & -1146 & -30.0\end{array}$

intent to leave: a nine-item factorially derived scale measuring the likelihood of a student's leaving the college.

Five independent variables were measured twice, once at the beginning of classes and again two months later. These were: orientation to job, value of education, confidence in success, educational commitment, and institutional commitment. In each case the operational definition was identical on both occasions. These five variables constituted repeated measures and permitted the assessment of changes in student attitudes and perceptions over time.

The criterion or dependent variables had four values, successful persister, unsuccessful persister, successful dropout, and unsuccessful dropout. Dropout in this study was defined from the institutional perspective. A student who left the subject institution during or at the end of the freshman year was classified as a dropout if he or she did not return to the same institution for the second year of studies. The operational definition for each criterion group was as follows: successful persisters: obtained an overall program average of $60 \%$ or more at the end of the first semester and continued their studies for the second and third semesters.

unsuccessful persisters: overall average at the end of the first semester was less than $60 \%$ and they continued their studies into the second and third semesters. successful dropouts: left college at the middle of the first semester with a mid-term average above $60 \%$, or left at the end of the first semester with a final grade average above $60 \%$.

unsuccessful dropouts: terminated their enrollment at mid-semester with a mid-term average below $60 \%$, or left the college at the end of the first semester with a final average below $60 \%$.

All statistical analyses were accomplished utilizing various computer programs available from the SAS software package (SAS Institute, 1982).

\section{RESULTS}

Table 1 shows that $30 \%$ of the students who began a Humber College program in the fall of 1986 dropped out during the freshman year. This figure is consistent with that reported by Stoll and Scarff (1983), who found an average freshman year dropout rate of $32 \%$ for the entire CAAT system between 1974 and 1979. Approximately half the students who left college did so in the first semester, either 
Table 2: First-Semester Dropouts by Type

\begin{tabular}{lcc} 
Dropout Type & N & \& \\
\hline Unsuccessful Dropout & 299 & 55.6 \\
Successful Dropout & 175 & 32.5 \\
Unclassified & 64 & 11.9 \\
Total & --- &
\end{tabular}

at mid-term or at the end of the semester. The remaining half departed at the middle or end of the second semester.

In financial terms this rate of attrition represents a loss to the college of approximately 7.2 million dollars in revenue. It would seem, therefore, that college administrators seeking to reduce the impact of shrinking revenues due to declining enrollments would be well advised to consider methods of reducing student attrition in their institutions.

Table 2 indicates that $55.6 \%$ of those who dropped out were academically unsuccessful, while $32.5 \%$ were successful. That is, not all dropout represents academic failure.

\section{Student Characteristics at Entry}

Mean socres by criterion group for each variable examined in this study are presented in Table 3. A comparison of the means for the background and entry-level characteristics of the two dropout groups with those of the successful persisters using Scheffé's multiple comparison procedure revealed several similarities and differences.

No statistically significant differences were observed between the successful dropouts (SD) and the successful persisters (SP) on both intellective and non-intellective measures at the beginning of classes. The unsuccessful dropouts (UD), on the other hand, differed on the intellective measures and were seen as being less capable academically than the successful persisters. For example, they had lower mean high school leaving averages and scored lower on the Nelson-Denny Reading test and a test of math skills. These findings are comparable to those of De Rome and Lewin (1984), Hackman and Dysinger (1970), Rose and Elton (1966), and Starr, Betz, and Menne (1972) for university students. In addition, it was found that at entry to the college the unsuccessful dropouts were less certain about their vocational goals and future occupation than were the successful persisters. In a college with a curricular focus on technical and vocational education, this characteristic is sure to be a liability.

Group differences on intellective measures were further clarified with chisquare analyses of the academic background variables for all four criterion groups. 
Table 3: Group Means for Study Variables

\begin{tabular}{lcccc} 
Variable Name & SP & UP & SD & UD \\
\hline Gender & 0.62 & 0.52 & 0.59 & 0.56 \\
Age & 20.7 & 20.1 & 22.0 & 20.2 \\
Socioeconomic status & 19.5 & 19.3 & 19.7 & 19.9 \\
Mother tongue & 0.20 & 0.26 & 0.19 & 0.30 \\
Prior education & 0.53 & 0.34 & 0.41 & 0.29 \\
Nelson-Denny Reading & 11.7 & 9.7 & 12.7 & 9.2 \\
Math placement test & 79.4 & 60.4 & 90.5 & 65.6 \\
High school average & 70.2 & 67.4 & 71.5 & 66.2 \\
H.S. program level & 0.41 & 0.70 & 0.53 & 0.71 \\
H.S. concentration & 0.33 & 0.61 & 0.39 & 0.35 \\
Changed residence & 0.34 & 0.17 & 0.33 & 0.27 \\
Financial aid & 0.22 & 0.18 & 0.24 & 0.18 \\
Rating of college & 0.77 & 0.73 & 0.79 & 0.77 \\
Rating of program & 0.94 & 0.90 & 0.98 & 0.95 \\
Educational goals & 24.8 & 24.5 & 24.3 & 24.5 \\
Concern for finances & 19.4 & 19.1 & 19.7 & 19.3 \\
College contact & 6.7 & 6.4 & 6.7 & 6.3 \\
Vocational uncertainty & 16.7 & 18.1 & 17.2 & 18.6 \\
Academic skill need & 30.2 & 32.2 & 30.8 & 32.2 \\
Actual p-t work & 0.59 & 0.71 & 0.58 & 0.76 \\
College service use & 10.0 & 10.8 & 10.2 & 10.4 \\
Dissatisfaction & 11.1 & 12.7 & 12.1 & 12.4 \\
Academic integration & 40.3 & 38.3 & 38.7 & 36.5 \\
Social integration & 69.7 & 69.4 & 68.8 & 68.5 \\
Value of education 1 & 19.6 & 19.5 & 19.5 & 19.5 \\
Value of education 2 & 19.8 & 19.7 & 19.4 & 19.2 \\
Confidence 1 & 19.8 & 19.0 & 19.6 & 19.4 \\
Confidence 2 & 20.1 & 18.6 & 18.4 & 17.5 \\
Job orientation 1 & 3.4 & 3.8 & 3.4 & 3.7 \\
Job orientation 2 & 3.4 & 4.1 & 3.8 & 4.3 \\
Educat. commit. 1 & 32.0 & 31.5 & 31.1 & 31.2 \\
Educat. commit. 2 & 31.8 & 30.4 & 28.3 & 27.5 \\
Instit. comnit. 1 & 19.6 & 19.3 & 19.6 & 19.4 \\
Instit. commit. 2 & 19.7 & 19.3 & 19.3 & 19.0 \\
Intent to leave & 15.3 & 18.9 & 19.7 & 21.5
\end{tabular}

The significant differences observed were between those students who were academically successful and those who were not, as is evident from Tables 4 and 5 .

Thus, the unsuccessful persisters (UP) and unsuccessful dropouts had a lower level of previous education when they enrolled in college, compared to the successful persisters and successful dropouts. They also came from a general level high school program rather than the advanced level program characteristic of the successful persisters and successful dropouts.

These findings are similar to those obtained from other studies which examined the secondary school characteristics of Ontario college dropouts (Stoll \& Scarff, 1983) and graduates (King, 1983). The findings of this study differ, however, in that it is clear that intellective measures alone cannot account for differentiated freshman attrition; students who scored high, as well as students who scored low on these variables, withdrew from college. 
Tabie 4: Chi-Square Test: Prior Education

\begin{tabular}{lcllc} 
Prior Education & SO & SP & UD & UP \\
\hline =< grade 12 & 55 & 676 & 71 & 80 \\
graduation & $58.5 \%$ & $47.1 \%$ & $71.0 \%$ & $66.1 \%$ \\
$>$ grade 12 & 39 & 758 & 29 & 41 \\
graduation & $41.5 \%$ & $52.9 \%$ & $29.0 \%$ & $33.9 \%$ \\
& & & & \\
& $x^{2}=37.49$ & df $=3$ & $p=0.0001$
\end{tabular}

\begin{tabular}{|c|c|c|c|c|}
\hline Table 5: & Chi-Squar & Test: Hig & \multicolumn{2}{|c|}{ chool Program Level } \\
\hline Program Level & SD & $S P$ & UD & UP \\
\hline $\begin{array}{l}\text { Advanced } \\
\text { level }\end{array}$ & $\begin{array}{c}44 \\
46.8 \%\end{array}$ & $\begin{array}{l}839 \\
58.5 \%\end{array}$ & $\begin{array}{c}29 \\
29.0 \%\end{array}$ & $\begin{array}{l}36 \\
29.7 \%\end{array}$ \\
\hline \multirow[t]{2}{*}{$\begin{array}{l}\text { General or } \\
\text { basic level }\end{array}$} & $\begin{array}{l}50 \\
53.2 \%\end{array}$ & $\begin{array}{l}595 \\
41.5 \%\end{array}$ & $\begin{array}{c}71 \\
71.0 \%\end{array}$ & $\begin{array}{l}85 \\
70.3 \%\end{array}$ \\
\hline & $x^{2}=67.50$ & $d f=3$ & $p=0$. & \\
\hline
\end{tabular}

\section{Student Characteristics at Mid-Semester}

A comparison of the attitudinal characteristics of the criterion groups at mid-semester showed that both dropout groups exhibited substantial differences from the successful persisters. Overall, they were less confident in their success, less academically and socially integrated, less committed to their education and to the institution, and had a higher intention to leave the college.

The identification of possible differences in the withdrawal process for the successful and unsuccessful dropouts was provided by the repeated measure variables. A t-test for dependent measures was conducted on each variable, examining the significance of the difference between the entry-level and mid-term means for each criterion group presented in Table 3. These data represent within-group attitudinal and behavioral changes and are summarized in Table 6 in terms of the mean change value for each group.

While the attitudes of the dropouts became more negative, those of the persisters either improved or remained unchanged. Differences observed between the two dropout groups suggested possible variations in the events leading to, and factors precipitating, withdrawal. The successful and unsuccessful dropouts were similar in that both groups exhibited a significant decrease in confidence in success and educational and institutional commitment, and an increase in their orientation to a 
Table 6: Change in Repeated Measure Variables

\begin{tabular}{|c|c|c|c|c|}
\hline Variable & & Criteri & Group & \\
\hline Name & $S P$ & UP & SD & UD \\
\hline Value of education & 0.26 * & 0.26 * & -0.12 & -0.29 \\
\hline Confidence in success & $0.30 *$ & -0.33 & $-1.13 \star$ & -1.84 \\
\hline Ed. Commitment & -0.20 * & $-1.15 \star$ & $-2.73 \star$ & -3.66 \\
\hline Inst. Commitment & 0.04 & 0.03 & $-0.26 *$ & -0.38 \\
\hline Academic Involvement & $0.16 \star$ & -0.62 * & -0.37 & -1.17 \\
\hline Job Orientation & 0.05 & 0.24 & $0.38 \star$ & 0.59 \\
\hline
\end{tabular}

* indicates significant change

job. The successful dropouts, however, showed neither a reduction in the perceived value of their education, nor a decline in their academic involvement in college as compared to high school.

Assuming a difference in academic ability between the two groups, as previous findings indicate, one might describe a possible sequence of events leading to the withdrawal of the unsuccessful dropouts. It would appear that both dropout groups began their studies with the same educational goals, perceived value of education, and commitment to graduation. The unsuccessful dropouts, however, were less certain about their occupational goals, and were less involved in studying, attending classes and completing homework assignments in high school.

Within the context of an academic environment lacking extrinsic rewards promoting high levels of involvement, such students were likely to begin skipping classes. This would have led to their falling behind in their courses, missing due dates for assignments, and failing class tests. In turn, these experiences would have resulted in reduced confidence in success, and negative perceptions of their program. Indeed, an alienation towards the college and its educational goals is suggested by the reductions in perceived value of education and institutional and educational commitment. This is further supported by the fact that this group increased its involvement in part-time employment above the level of its expectation at the start of classes, and increased in its orientation to an outside job. 
College departure for this group seems most likely to have been the product of a cumulative process beginning with poor academic and study skills, and vocational uncertainty, leading to failure, dissatisfaction, and alienation, and culminating in withdrawal from the college.

While it is clear that academic failure played a significant role in the departure of the unsuccessful group, this is certainly not true of the successful dropouts. It is more likely that the negative perceptions of the institution and their program which developed over the first-half of the semester were most instrumental in the dropout of the successful group. Indeed, this group maintained its academic involvement and perceived value of education, suggesting that these students may have transferred to another college, either at the beginning of the second semester or the following fall. Their significantly increased orientation to a job, however, indicates that they could have also entered the workforce.

The cause of these negative perceptions may have been the result of insufficient academic challenge for this group. They recorded the highest mean high school leaving average, Nelson-Denny Reading test, and math placement test scores of all the groups. This, combined with a somewhat higher mean age of 22 years compared to 20 years for the other groups, suggests that perhaps this group was not sufficiently stimulated intellectually and found the college environment unsuited to their needs.

Table 7 presents the results of a multiple discriminant analysis of the four criterion groups and shows that the new model of dropout accounted for $25 \%$ of the variance between the groups. Those variables identified with an asterisk have structure coefficients above 0.30 (Pedhazur, 1982) and suggest that the dimension on which the groups differed might best be described by the term educational certainty. Students who were academically successful and who persisted in their program were more involved in, and committed to, their education, and more confident in their success, compared to those who were unsuccessful and dropped out.

The analysis also indicated that the level of a student's integration into his or her academic program was most effective in differentiating between the groups. The strength of the student's intention to leave the college at mid-term, the level of programming followed in high school, and changes in confidence and educational commitment also made significant contributions to group discrimination, in descending order of importance. Thus, the main constructs of both Tinto and Bean were found to be important in distinguishing between successful and unsuccessful persisters and successful and unsuccessful dropouts.

\section{Determinants of Freshman Attrition}

These results suggest that in a commuter college with a focus on technical/ vocational education, persistence is determined primarily by a student's integration into the academic environment and by his or her educational commitment at the middle of the first semester. Within the context of Tinto's model it is clear that 


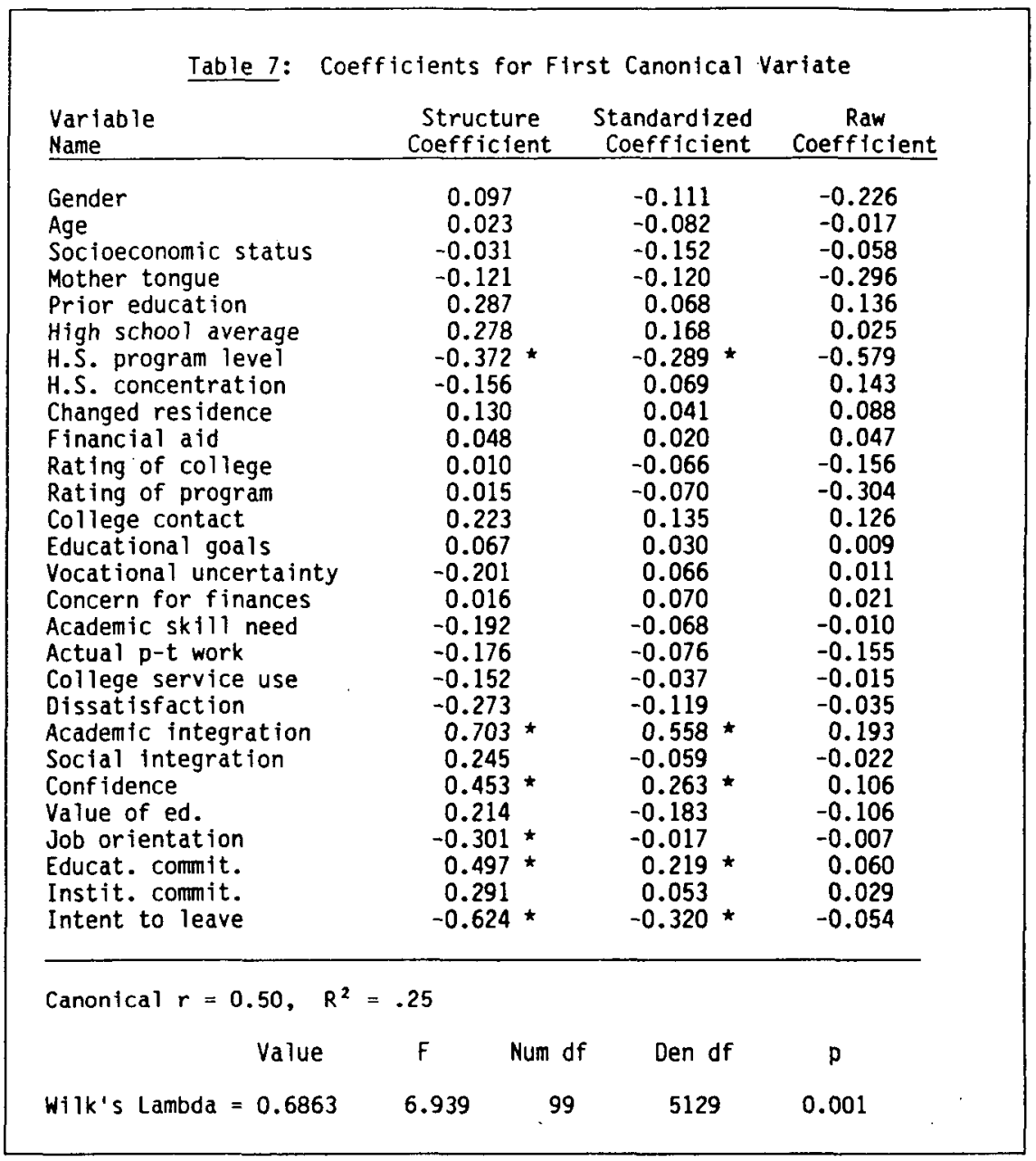

the above two constructs are instrumental in explaining student persistence vs withdrawal, while those of institutional commitment and social integration are much less important. This is consistent with the findings obtained by Pascarella and his colleagues (Pascarella \& Chapman, 1983a; Pascarella, Duby, \& Iverson, 1983) for commuter colleges. Thus, the factors which determine persistence in the commuter college are different from those in the residential university. In the former, student involvement with faculty, peers, and extracurricular activities is of considerably less importance in determining persistence. What is of major importance, is the student's perception of his or her program as an intellectually stimulating and rewarding activity, which will be of value to his or her future occupational success. Likewise the degree of student involvement in the academic behaviors of attending classes, studying, and completing homework assignments 
makes a significant contribution to the determination of persistence. The importance of Bean's constructs of intent to leave and confidence was also clearly demonstrated and argues for their inclusion in a revised model of dropout.

The relative importance of background and student-institution interaction variables was examined in this study by conducting discriminant analyses comparing persisters and dropouts. Three different sets of independent variables were used with each analysis, resulting in a $\mathrm{F}$ statistic significant at the 0.0001 level. It was found that while the utilization of information on the background, entry-level, interaction, and outcome characteristics of students accounted for the greatest amount of variance in dropout $\left(\mathrm{R}^{2}=.25\right)$, the interaction and outcome set alone $\left(\mathrm{R}^{2}=.14\right)$ accounted for three times the amount of variance explained by only the background and entry-level set $\left(R^{2}=.044\right)$. Thus, the factors which promoted persistence in the sample of commuter college freshmen examined in this study were a product of the interaction between the student and the institution, rather than simply the background and entry-level characteristics of the students themselves. This is certainly consistent with the person-environment fit models of dropout described in the literature and suggests that it is possible for those who manage institutions of higher education to improve persistence in their freshman clientele. In essence, the two groups who dropped out in this study did so because of a poor "fit" between their characteristics and those of the institution. For the unsuccessful dropouts the academic demands were too great, while for the successful dropouts they were not high enough. Further research is required to elaborate on this interpretation.

An important first step in dropout prevention would involve the identification of potential dropouts as they enter the institution. Such "early-warning" systems have been cited in the literature as important components of retention programs (Noel, Levitz, \& Kaufmann, 1982). Discriminant classification analyses indicated that it would be possible to predict dropout/persistence with an accuracy greater than chance by gathering information on freshman student characteristics. While it would be feasible to make such predictions using only background and entry-level information, Table 8 shows that the most accurate predictions can be made only when this is combined with information on student attitudes and behavior during the first-half of the first semester.

This is consistent with the finding that dropout/persistence is highly influenced by the latter set of variables. Thus, it would be possible to make relatively accurate predictions regarding student persistence at the middle of the first semester. This is too late, perhaps, to reverse the dropout decision for some students, but certainly not too late for the vast majority who, as was seen, leave the institution at the end of the first or second semester.

\section{IMPLICATIONS FOR RETENTION}

The results of this study have implications for retention both in terms of how colleges are managed and the specific policies and procedures which could increase freshman persistence. 


\begin{tabular}{|c|c|c|c|c|}
\hline \multirow{2}{*}{$\begin{array}{l}\text { Set of } \\
\text { Varfables }\end{array}$} & \multicolumn{4}{|c|}{$\begin{array}{l}\text { Classification Accuracy by Variable Set } \\
\text { Percent of Cases Correctly Classified }\end{array}$} \\
\hline & SD & $S P$ & UD & UP \\
\hline $\begin{array}{l}\text { Background and } \\
\text { Entry-Level }\end{array}$ & 38.3 & 42.5 & 44.0 & 52.1 \\
\hline $\begin{array}{l}\text { Mid-Term } \\
\text { Set }\end{array}$ & 35.1 & 64.2 & 44.0 & 34.7 \\
\hline $\begin{array}{l}\text { All } \\
\text { Vartables }\end{array}$ & 40.4 & 63.5 & 59.0 & 54.5 \\
\hline
\end{tabular}

The responsibility for initiating efforts to improve student retention falls within the jurisdiction of college administrators and involves the policy decision to implement a comprehensive and coordinated program of institutional research. Indeed, Dennison and Gallagher (1986) in their critical analysis of Canada's community colleges have indicated that this activity is rarely associated with the responsibility of a public community college. The authors further state,
Absence of research of this kind is a major omission on the part of colleges. It leaves a college with no real insights into its operation, no appreciation of the heterogeneity of its students, no understanding of its impact upon the workforce, and no valid basis for assessing its style of operation. A blind repetition of established practices - in admission policy, in instructional methodology, or curriculum organization - based upon untested assumptions carried from the past will neither enhance the quality of instruction nor justify its continued existence before government or public. (Dennison \& Gallagher, 1986, p. 265)

In fact, most college administrators, in contrast to the suggestions made by Peters and Waterman (1982) regarding the qualities of excellent organizations, have little information on what is really going on in their institutions from the perspective of the student. They are not "close to their clients". Indeed, the senior managers of most, if not all, colleges have no idea what their dropout rate is because this group tends to subscribe to the "passive" philosophy of education; all that is required of them is to provide the necessary inputs of facilities, faculty, and programs and some students will succeed while others will not. Panos and Astin (1968) found such climates characterized institutions with higher dropout rates. Futhermore, most administrators assume that the principal factors promoting student failure/dropout are associated with the student, not the institution. The student simply "did not have what it takes" to be successful. This study has demonstrated, however, that this is not the case and suggests that the success or failure of students depends upon the nature of their college experiences. Students who fail/dropout in one type of environment could succeed/persist in another.

What is required is the implementation of a planning and management or decision support system of the type described by Sheehan (1982). Such a system was utilized in this study and demonstrates the means for improving both retention 
and institutional effectiveness. What is involved is the creation of a computermanaged data base with information on student background, entry-level, interaction, and outcome characteristics, as well as course grades. This information might be termed a Student-Oriented Decision Support System and may be utilized to introduce necessary feedforward and feedback elements into the higher education system. Specific details of these procedures are provided in Dietsche, 1990 (in press). The implementation of this decision support system could provide college administrators with valuable information which they presently do not possess: information on what is actually happening to freshmen within their institution. The utilization of this information in planning and decision-making activities could provide the means for reducing attrition, bolstering financial resources, and improving the quality of education for Ontario college students.

\section{REFERENCES}

Anisef, P., Paasche, J.G., \& Turrittin, A. (1980). Is the die cast? Educational achievements and work destinations of Ontario youth: A six year follow-up of the critical juncture of high school students. Toronto, Ontario: Ministry of Colleges and Universities.

Astin, A. (1972a). College dropouts: A national profile. Washington, D.C.: American Council on Education.

(1975). Preventing students from dropping out. San Francisco: Jossey-Bass.

Bayer, A., Royer, J.T., \& Webb, R. (1973). Four years after college. (ACE Research Report No. 8). Washington, D.C.: American Council on Education. (ERIC Document Reproduction Service No. ED 077329)

Beal, P., \& Noel, L. (1980). What works in student retention. Iowa City, Iowa, and Boulder, Colo.: American College Testing Program and the National Center for Higher Education Management Systems.

Bean, J.P. (1980). Dropouts and turnover: The synthesis and test of a causal model of student attrition. Research in Higher Education, 12, 155-187.

. (1983). The application of a model of turnover in work organizations to the student attrition process. Review of Higher Education, 6, 129-148.

Cope, R. \& Hannah, W. (1975). Revolving college doors: The causes and consequences of dropping out, stopping out and transferring. New York: Wiley-Interscience.

Dennison, J., \& Gallagher, P. (1986). Canada's community colleges: A critical analysis. Vancouver: University of British Columbia Press.

De Rome, E., \& Lewin, T. (1984). Predicting persistence at university from information obtained at intake. Higher Education, 13, 49-66.

Dietsche, P.H.J. (1989). Describing and predicting freshman attrition in a College of Applied Arts and Technology. Unpublished doctoral dissertation, University of Toronto: Toronto, Ontario.

Dietsche, P.H.J. (1990). Managing community colleges for student success. Planning in Education (in press).

Eckland, B.K. (1964a). College dropouts who came back. Harvard Educational Review, 34, $402-420$.

Gilbert, S.N., \& Gomme, I.M. (1986). Future directions in research on voluntary attrition from colleges and universities. College and University, 61, 227-238.

Gomme, I.M., \& Gilbert, S.N. (1984). Paying the cost: Some observations on the problem of postsecondary student attrition. Canadian Journal of Higher Education, 14, 95-100.

Grites, T.J. (1979). Academic advising: Getting us through the eighties. (Higher Education Research Report No. 7). Washington, D.C.: American Association of Higher Education. 
Hackman, R., \& Dysinger, W. (1970). Commitment to college as a factor in student attrition. Sociology and Education, 43, 311-324.

Hanson, G., \& Taylor, R. (1970). Interaction of ability and personality: Another look at the dropout problem in an institute of technology. Journal of Counselling Psychology, 17, 540-545.

Hart, J.D. (1988). A history of the development of the curriculum guidelines for post-secondary programmes of the Ontario colleges of applied arts and technology, 1972-1986. Unpublished doctoral dissertation, University of Toronto, Toronto.

Jex, F.B., \& Merrill, R.M. (1962). A study in persistence. Personnel and Guidance Journal, 40, $762-769$.

Jones, G., \& Dennison, J.D. (1972). A comparative study of persister and non-persister college students. (ERIC Document Reproduction Service No. ED 062975).

King, A.J.C. (1983). Who goes to college? Ontario Secondary School Teachers' Federation Research in Secondary Education, \#5. Toronto: Ontario, The Provincial Research Committee of the Ontario Secondary School Teachers' Federation.

Knoell, D. (1960). Institutional research on retention and withdrawal. In H.T. Sprague (Ed.), Research on College Students. Boulder Colo.: and Berkeley, Calif.: The Western Interstate Commission for Higher Education, and The Center for the Study of Higher Education. 41-65.

Lam, Y.L. (1984). Predicting dropouts of university freshmen: A logit regression analysis. The Journal of Educational Administration, 22, 74-82.

Lenning, O., Beal, P. \& Sauer, K. (1980). Retention and attrition: Evidence for action and research. Boulder, Colo.: National Center for Higher Education Management Systems.

Marks, E. (1967). Student perceptions of college persistence and their intellective, personality, and performance correlates. Journal of Educational Psychology, 58, 210-221.

Mehra, N. (1973). Retention and withdrawal of university students: A study of academic performance of a freshman class. Alberta: University of Alberta. (ERIC Document Reproduction Service No. ED 087296).

Munro, B.H. (1981). Dropouts from higher education: Path analysis of a national sample. American Educational Research Journal, 18, 133-141.

Noel, L., Levitz, R., \& Kaufmann, J. (1982). Organizing the campus for retention: A report of $a$ national study. Iowa City, Iowa: ACT National Center for the Advancement of Educational Practices.

O'Brian, W.E. (1967). A study of student levels of satisfaction with community college and senior college instructional services. Unpublished doctoral dissertation, Northem Illinois University.

Panos, R., \& Astin, A. (1968). Attrition among college students. American Educational Research Journal, 5, 57-72.

Pantages, T., \& Creedon, C. (1978). Studies of college student attrition: 1950-1975. Review of Educational Research, 48, 49-101.

Pascal, C., \& Kanowitch, S. (1979). Student withdrawals from Canadian universities: A study of studies. Toronto, Ontario: The Ontario Institute for Studies in Education, Higher Education Group.

Pascarella, E.T., \& Chapman, D.W. (1983). A multi-institutional, path analytic validation of Tinto's model of college withdrawal. American Educational Research Journal, 20, 87-102.

Pascarella, E.T., Duby, P.B., \& Iverson, B.K. (1983). A test and reconceptualization of a theoretical model of college withdrawal in a commuter institution setting. Sociology of Education, 56, $88-100$.

Pascarella, E.T., Duby, P.B., Miller, V.A., \& Rasher, S.P. (1981). Preenrollment variables and academic performance as predictors of freshman year persistence, early withdrawal, and stopout behavior in an urban, nonresidential university. Research in Higher Education, 15, 329-349.

Pascarella, E.T., \& Terenzini, P.T. (1983). Predicting voluntary freshman year persistence/ withdrawal behavior in a residential university: A path analytic validation of Tinto's model. Journal of Educational Psychology, 75, 215-226. 
Pedhazur, E.J. (1982). Multiple regression in behavioral research: Explanation and prediction (2nd ed.). New York: Holt, Rinehart and Winston.

Peters, T.J., \& Waterman, R.H. (1982). In search of excellence: Lessons from America's best-run companies. New York: Harper and Row.

Prediger, D.J. (1965). Prediction of persistence in college. Journal of Counseling Psychology, 12, $62-67$.

Ramist, L. (1981). College student attrition and retention. (Report No. 81-1). New York, N.Y.: College Entrance Examination Board.

Rose, H.A., \& Elton, C.F. (1966). Another look at the college dropout. Journal of Counseling Psychology, 13, 242-245.

SAS Institute Inc. (1982). SAS user's guide: Statistics, 1982 edition. Cary, N.C.: SAS Institute Inc.

Sheehan, B.S. (1982). Decision support systems: An institutional perspective. Paper presented at 22nd Forum of the Association for Institutional Research. Denver, Colo.: May 19, 1982.

Spady, W. (1970). Dropouts from higher education: An interdisciplinary review and synthesis. Interchange, $I, 109-121$.

Starr, A., Betz, E.L., \& Menne, J. (1972). Differences in college student satisfaction: Academic dropouts, nonacademic dropouts, and nondropouts. Journal of Counseling Psychology, 19, 318-322.

Stoll, R., \& Scarff, E. (1983). Student attrition from postsecondary programs at the Ontario Colleges of Applied Arts and Technology. Toronto, Ontario: Ministry of Colleges and Universities, Special Projects Office.

Terenzini, P.T., \& Pascarella, E.T. (1977). Voluntary freshman attrition and patterns of social and academic integration in a university: A test of a conceptual model. Research in Higher Education, 6, 25-43.

(1978). The relation of student's precollege characteristics and freshman year experience to voluntary attrition. Research in Higher Education, 9, 347-366.

. (1984). Freshman attrition and the residential context. The Review of Higher Education, 7, 111-124.

Tinto, V. (1975). Dropout from higher education: A theoretical synthesis of recent research. Review of Educational Research, 45, 89-125.

. (1982). Limits of theory and practice in student attrition. Journal of Higher Education, 53, $687-700$

(1986). Leaving college: Rethinking the causes and cures of student attrition. Chicago: The University of Chicago Press.

Ungar, S. (1980). The retention problem: An analysis of enrollment attrition at a Canadian college. The Canadian Journal of Higher Education, 10, 57-74.

Zaccaria, L., \& Creaser, J. (1971). Factors relating to persistence in an urban commuter university. Journal of College Student Personnel, 12, 256-291. 